medRxiv preprint doi: https://doi.org/10.1101/2020.09.24.20201236; this version posted September 25, 2020. The copyright holder for this preprint (which was not certified by peer review) is the author/funder, who has granted medRxiv a license to display the preprint in perpetuity.

It is made available under a CC-BY-NC-ND 4.0 International license .

\title{
Behavioural barriers to COVID-19 testing in Australia
}

\section{Authors:}

Carissa Bonner, Carys Batcup, Julie Ayre, Kristen Pickles, Rachael Dodd, Tessa Copp, Samuel Cornell, Erin Cvejic

Thomas Dakin, Jennifer Isautier, Brooke Nickel, Kirsten McCaffery

\section{Affiliations:}

Sydney Health Literacy Lab, School of Public Health, Faculty of Medicine and Health

The University of Sydney

\section{Correspondence:}

Dr Carissa Bonner

Rm 128A, Edward Ford Building A27 | The University of Sydney | NSW | 2006

$T+61293517125 \mid F+61293515049$

E carissa.bonner@sydney.edu.au 
medRxiv preprint doi: https://doi.org/10.1101/2020.09.24.20201236; this version posted September 25, 2020. The copyright holder for this preprint (which was not certified by peer review) is the author/funder, who has granted medRxiv a license to display the preprint in perpetuity.

It is made available under a CC-BY-NC-ND 4.0 International license .

\section{ABSTRACT}

Background: The current suppression strategy for COVID-19 in Australia is dependent on people getting tested and self-isolating while they have COVID-19 symptoms. However, there is very little research on the behaviours and behavioural barriers involved in getting tested, both in Australia and worldwide, despite there being some evidence that these barriers do exist.

Methods: The Sydney Health Literacy Lab (SHeLL) has been conducting a national longitudinal survey in Australia since April 2020. A list of testing barriers was included in Wave 3 in June 2020 ( $n=1369$ ), along with intentions to test and self-isolate if symptomatic. Open responses were also collected. The test barriers identified were categorised using the COM-B framework.

Results: Only 49\% of people strongly agreed they would get tested if they had COVID-19 symptoms, but most people agreed to some extent that they would get tested (96\%). The most common barriers selected from the list provided were that testing is painful (11\%), not knowing how to get tested $(7 \%)$, and worry about getting infected at the testing centre (5\%). Many participants (10\%) indicated other reasons, and open responses included many additional barriers to testing than those provided in the initial list. These covered all components of the COM-B model.

Conclusion: We identified a wide range of barriers using both quantitative and qualitative methods, which need to be addressed in order to increase COVID-19 testing behaviour. 


\section{BACKGROUND}

The current suppression strategy for COVID-19 in Australia is dependent on people getting tested and selfisolating while they have COVID-19 symptoms (e.g. fever, cough, sore throat). According to the COM-B model, COVID-19 prevention behaviours can be conceptualised in terms of three main drivers: physical/psychological capability (e.g. having the physical ability to drive to and walk up the stairs to access a testing centre, and knowing what to do if you get a cough), physical/social opportunity (e.g. the availability of testing centres in your area, and social norms that make self-isolation acceptable), and automatic/reflective motivation (e.g. getting into the habit of staying home when you have symptoms, and believing that it's important to get tested if you develop symptoms $)^{1}$. Furthermore, a person who is already motivated to test will require different strategies (e.g. to overcome specific access barriers) than a person who does not see the value in testing and is not motivated to test. For example, the Health Action Process Approach suggests that intentions are driven by risk perception about the threat, self efficacy to take action to reduce the threat, and what you expect the outcomes of the threat and action will be ${ }^{2}$. But to translate intentions into behaviours, you also need to plan exactly what you will do (action planning) and how you will address barriers to that plan (coping planning $)^{2}$

There is little research on COVID-19 testing behaviours given the very new nature of this issue, but current literature and media reports suggest different barriers exist across countries. For example, countries such as Tanzania have major issues with opportunity in terms of limited access and fake testing kits ${ }^{3}$. Cost may be a barrier in other countries such as the US where health insurance may not cover the testing. This disproportionately affects certain groups such as immigrant and non-citizen communities, who may also fear financial and legal repercussions from testing positive ${ }^{4}$. Furthermore, testing may be limited to certain criteria (e.g. only if you have symptoms, regardless of exposure to COVID-19 cases) due to lack of supply or staff resource issues ${ }^{5}$. There may also be issues of delivering tests and transporting samples for remote areas ${ }^{6}$. Finally, there may be issues with inadequate communication and low community knowledge about which symptoms require testing and the process to follow ${ }^{5}$. 
medRxiv preprint doi: https://doi.org/10.1101/2020.09.24.20201236; this version posted September 25, 2020. The copyright holder for this preprint (which was not certified by peer review) is the author/funder, who has granted medRxiv a license to display the preprint in perpetuity.

It is made available under a CC-BY-NC-ND 4.0 International license .

Australia is fortunate to have efficient and freely accessible testing widely available, although this can vary by location. Testing clinics have been set up all around the country including drive through options to minimise contact with other patients, and results are generally sent by text message within 2 days ${ }^{7,8}$. However, the process can take longer and is unpredictable where demand increases in new outbreak areas such as Victoria in July-September $2020^{9-11}$.

We know that certain groups are less likely to understand and act on COVID-19 prevention advice. For example, people with lower health literacy and those who speak a language other than English were less likely to be able to identify COVID-19 symptoms and prevention measures ${ }^{12}$. Younger people, men and those with less education were more likely to agree with COVID-10 misinformation about prevention, management and cure $^{13}$. These groups likely need different communication strategies to ensure everyone understands the message and takes appropriate action based on the message.

Messaging trials have tested different strategies to improve intentions to follow COVID-19 prevention advice, for example framing the motivation as helping the community rather than avoiding individual risk $^{14}$, or testing identity-based messages such as "don't be a spreader"15. However, emerging research in this area is generally not peer reviewed and has neglected testing as a key behavioural outcome for COVID-19 prevention. We need to understand the behavioural barriers ${ }^{1}$ to testing in order to develop and evaluate interventions to address these issues. 
medRxiv preprint doi: https://doi.org/10.1101/2020.09.24.20201236; this version posted September 25, 2020. The copyright holder for this preprint (which was not certified by peer review) is the author/funder, who has granted medRxiv a license to display the preprint in perpetuity.

It is made available under a CC-BY-NC-ND 4.0 International license .

AIM

This study aims to address a major gap in our understanding about how to improve COVID-19 testing

behaviour, by: 1) reporting the prevalence of specific test barriers in an Australian survey sample; 2) identifying

additional test barriers through open responses, since research on this is still emerging; and 3) linking these

barriers to an overarching framework of behaviour change.

\section{METHOD}

\section{National survey}

The Sydney Health Literacy Lab (SHeLL) has been conducting a national longitudinal survey in Australia since April $2020^{12,13}$. The original sample was recruited via an online market research panel, supplemented with social media advertising $(n=4326)$. The social media users were followed-up monthly from April-July. A list of testing barriers of interest to the NSW Department of Health was included in Wave 3 in June 2020 ( $n=1369)$, along with intentions to test and self-isolate if symptomatic. These were worded as: "over the next 4 weeks, I plan to get tested if I have COVID-19 symptoms (cough, sore throat, fever)" and "over the next 4 weeks, I plan to stay home if I have COVID-19 symptoms (cough, sore throat, fever)"; with 1-7 response options from strongly disagree to strongly agree. Open responses to "other" test barriers were also collected. Descriptive analyses are reported as percentages for the survey results.

\section{COM-B behavioural diagnosis}

The test barriers identified from the survey responses were categorised using the COM-B framework ${ }^{16}$ by 2 researchers who have been trained in the use of this framework ( $C B$ and $C A B) . C A B$ conducted the initial coding, and this was reviewed by CB with discussion of issues that could be coded in different ways until consensus was reached. 
medRxiv preprint doi: https://doi.org/10.1101/2020.09.24.20201236; this version posted September 25, 2020. The copyright holder for this preprint (which was not certified by peer review) is the author/funder, who has granted medRxiv a license to display the preprint in perpetuity.

It is made available under a CC-BY-NC-ND 4.0 International license .

\section{RESULTS}

The results of the survey questions are reported in Tables 1-2. Only 49\% of people strongly agreed they would get tested if they had COVID-19 symptoms (cough, fever, sore throat), but most people agreed to some extent that they would get tested (96\%). For self-isolation, $69 \%$ strongly agreed they would stay home if they had symptoms. The most common barriers selected from the list provided were that testing is painful $(11 \%)$, not knowing how to get tested ( $7 \%)$, and worry about getting infected at the testing centre (5\%). Many participants (10\%) indicated other reasons, and open responses included many additional barriers to testing than those provided in the initial list. Table 3 maps all the barriers identified in open survey responses to the COM-B drivers of behaviour, covering all components. 
Table 1: Intentions if symptomatic for COVID-19 over the next 4 weeks

\begin{tabular}{|l|r|r|}
\hline Intention to get tested if symptomatic in next 4 weeks & $\mathbf{n}$ & \% \\
\hline Strongly agree & 674 & 49.1 \\
\hline Agree & 376 & 27.4 \\
\hline Somewhat agree & 101 & 7.4 \\
\hline Neither agree nor disagree & 72 & 5.2 \\
\hline Somewhat disagree & 40 & 2.9 \\
\hline Disagree & 49 & 3.6 \\
\hline Strongly disagree & 60 & 4.4 \\
\hline Intention to self-isolate if symptomatic in next 4 weeks & $\mathbf{n}$ & \% \\
\hline Strongly agree & 951 & 69.3 \\
\hline Agree & 310 & 22.6 \\
\hline Somewhat agree & 53 & 3.9 \\
\hline Neither agree nor disagree & 12 & 0.9 \\
\hline Somewhat disagree & 14 & 1.0 \\
\hline Disagree & 6 & 0.4 \\
\hline Strongly disagree & 26 & 1.9 \\
\hline
\end{tabular}

Table 2: Barriers to testing if symptomatic for COVID-19

\begin{tabular}{|c|c|c|}
\hline Testing barrier & $\mathbf{n}$ & $\%$ \\
\hline Testing is painful & 153 & 11.2 \\
\hline Other (please detail) - see Table 3 & 136 & 9.9 \\
\hline I don't know how, when and where to get tested & 98 & 7.1 \\
\hline I'm worried I will get infected with COVID-19 at the testing clinic & 81 & 5.9 \\
\hline I'll forget to get tested & 33 & 2.4 \\
\hline I'm worried about what others think of me & 32 & 2.3 \\
\hline It's too difficult or expensive to get tested & 29 & 2.1 \\
\hline Testing doesn't work / I don't trust the results & 17 & 1.2 \\
\hline No one else is getting tested & 11 & 0.8 \\
\hline
\end{tabular}


Table 3: COM-B drivers of COVID-19 testing behaviour

\begin{tabular}{|c|c|c|}
\hline COM-B & Barrier & Example quotes from "other" barriers ( $10 \%$ of sample): open survey responses \\
\hline \multirow{3}{*}{$\begin{array}{l}\text { Physical } \\
\text { capability }\end{array}$} & Disability means I can't get a test & Fear of injury from getting tested - I have a deviated septum and narrow sinuses \\
\hline & $\begin{array}{l}\text { Need a ramp/disability provisions for the } \\
\text { testing centre }\end{array}$ & Testing facilities can't accommodate my disability so it's better for me just to stay home \\
\hline & Physically can't drive/access testing centre & I'm homebound due to severe disability so I know arranging testing will be super hard \\
\hline \multirow[t]{4}{*}{$\begin{array}{l}\text { Psychological } \\
\text { capability }\end{array}$} & $\begin{array}{l}\text { Getting conflicting information/being told not } \\
\text { to get tested even with symptoms }\end{array}$ & $\begin{array}{l}\text { When I first got sore throat, headache, aches, cough, and partner very lethargic I got tested, and } \\
\text { had the impression from testers that it wasn't necessary with only those symptoms }\end{array}$ \\
\hline & Unsure how to get tested & Also I dont know how to drive so I dont know how to get to places that test \\
\hline & Unsure if symptoms are bad enough & $\begin{array}{l}\text { Believing that I don't meet the threshold eg when is a cough a cough or a runny nose with spicy food } \\
\text { a runny nose? Otherwise I would get tested. }\end{array}$ \\
\hline & Unsure if symptom needs testing & I am not sure whether I would be eligible to be tested \\
\hline \multirow{7}{*}{$\begin{array}{l}\text { Physical } \\
\text { opportunity }\end{array}$} & Centres are hard to access & Hard to get to where I can get tested \\
\hline & Opening hours don't suit & Being able to get to the testing clinic within opening hours when caring for children \\
\hline & Don't want to take public transport & Public transport required to get to testing centre is inappropriate \\
\hline & Need to take time off work & Hard to find the time with increased workload \\
\hline & Don't have enough time to get tested & Just tooooo busy - work during COVID \\
\hline & Don't have childcare & Depends on if I can get childcare and can find the time \\
\hline & Financial repercussions to getting tested & $\begin{array}{l}\text { My husbands test took } 10 \text { days to get results. Which meant he could not work. He is self employed } \\
\text { which means he also did not get paid and lost } 8 \text { days of income }\end{array}$ \\
\hline $\begin{array}{l}\text { Social } \\
\text { opportunity }\end{array}$ & Worried what others will think & $\begin{array}{l}\text { I will certainly feel worried about what others think of me, especially people who lives in the same } \\
\text { household }\end{array}$ \\
\hline \multirow[t]{3}{*}{$\begin{array}{l}\text { Reflective } \\
\text { motivation }\end{array}$} & Bad experience when I got tested previously & $\begin{array}{l}\text { We had a bad experience getting my son tested... I can't afford to be off work for } 5 \text { days just to chase } \\
\text { down a negative result }\end{array}$ \\
\hline & $\begin{array}{l}\text { The process of testing is too much hassle for } \\
\text { risk }\end{array}$ & There is a very tiny chance it will actually be COVID-19 so waste of time. \\
\hline & The test is painful & It hurt last time I got tested \\
\hline
\end{tabular}




\begin{tabular}{|c|c|c|}
\hline & Worried about spreading your illness & Have to ask someone to take me to a clinic and don't want to get them sick \\
\hline & Worried about catching COVID-19 & $\begin{array}{l}\text { I'm immunocompromised so don't want to be around others in case I get sick (not spefically [SIC] } \\
\text { covid) }\end{array}$ \\
\hline & Don't want to hear that I'm positive & Will only get tested if I have a fever. Also, "too scared" to know the results! \\
\hline & $\begin{array}{l}\text { Don't think the testing works or results are } \\
\text { reliable enough }\end{array}$ & The accuracy of tests does concern me a bit \\
\hline & Don't want to self-isolate after the test & Requirement to quarantine between test and getting results \\
\hline & There are other options than getting tested & Don't think it's necessary to test, just isolate \\
\hline & Symptoms due to something else & $\begin{array}{l}\text { The symptoms are the same as my normal June sniffles I wouldn't bother, unless I get other unusual } \\
\text { symptoms }\end{array}$ \\
\hline & Already tested negative & $\begin{array}{l}\text { I was tested last week. If this residual cough remains I am unlikely to get retested. If I get new } \\
\text { symptoms I would get retested }\end{array}$ \\
\hline & $\begin{array}{l}\text { Will wait for symptoms to get worse } \\
\text { first/threshold }\end{array}$ & $\begin{array}{l}\text { I'll get tested if the symptoms last for more than } 24 \text { hours } \\
\text { if its just something like runny nose but no other symptoms show up - No but if I have more than } 1 \\
\text { then I'll get tested }\end{array}$ \\
\hline & Don't believe it can be covid as it's so rare & No community transmission, highly unlikely to be COVID-19 \\
\hline & Will only get a test if advised by GP & Get tested if my dr refers me to be tested \\
\hline & It may result in problems with work/visa & Might be excluded from starting a new job \\
\hline & Herd immunity beliefs & I believe in herd immunity \\
\hline $\begin{array}{l}\text { Automatic } \\
\text { motivation }\end{array}$ & I am scared of the test & Afraid of the uncomfortable test \\
\hline
\end{tabular}




\section{DISCUSSION}

This paper provides insights into testing barriers in Australia, showing that they cover all possible theoretical drivers of behaviour: capability, opportunity and motivation. Since this is such a complex issue, it requires a multifaceted approach to address.

For capability barriers, we know that government information about COVID-19 is difficult to understand for the average person based on readability analyses ${ }^{17}$, and that communities with different language needs are not being adequately addressed ${ }^{18}$. We have also identified that certain groups are more sucsceptible to misinformation, such as younger people and $\operatorname{men}^{13}$. Addressing different information needs in the community may require using less traditional news sources ${ }^{19}$ and different spokespeople to reach these groups, such as social media influencers ${ }^{20}$.

Although the Australian testing system is comparatively accessible, there are still opportunity barriers particularly around financial losses and work expectations that require system changes. Victoria has addressed this during the recent outbreak by providing financial support for those who are self isolating ${ }^{21}$. There are also social opportunity issues where stigma and perceived judgment by others could prevent individuals from getting tested, which we have seen in other infectious disease conditions such as HIV ${ }^{22}$.

The largest category of barriers in this study was motivation, which is likely to influence both intentions and behaviours. To address low intentions to test we need to identify and address the specific concerns that each individual has, as they are so wide ranging. For some people, online symptom checkers could be a channel to provide tailored information, where users could be prompted for key concerns to link them to the most relevant information ${ }^{23,24}$, as opposed to searching for this in long FAQ pages on government health websites. However, they are not all reliable ${ }^{25}$, and may not be accessed by some groups such as culturally and linguistically diverse communities. To address gaps between intentions and actual behaviour, we could help people to plan in advance for the inconvenience of testing and self isolation, for example a person could have a plan worked out in advance with their manager for how they will notify work and change shifts or work from 
medRxiv preprint doi: https://doi.org/10.1101/2020.09.24.20201236; this version posted September 25, 2020. The copyright holder for this preprint (which was not certified by peer review) is the author/funder, who has granted medRxiv a license to display the preprint in perpetuity.

It is made available under a CC-BY-NC-ND 4.0 International license .

home. Setting goals in advance has been shown to change various health-related behaviours ${ }^{26,27}$, and this strategy has been applied in Australia to help communities plan for bushfire management ${ }^{28}$.

Our findings from June are very similar to September results from national flu tracking data, which show $51 \%$ of people who experienced COVID-19 symptoms did not get tested ${ }^{29}$. Our findings show $51 \%$ of people did not "strongly agree" they would get tested, but most people agreed to some extent and addressing barriers may improve this overall positive orientation and address the behaviour gap. Another survey conducted in August found much higher rates of testing avoidance, and reported $85 \%$ of respondents who had sympoms had not been tested ${ }^{30}$.

In conclusion, we identified a wide range of barriers using both quantitative and qualita tive methods, which need to be addressed in order to increase testing behaviour. Interventions to improve testing uptake need to identify key barriers for target populations, and specifically address these using evidence-based behaviour change techniques. Our findings support broader advice from international experts in behaviour change, highlighting the importance of diagnosing behavioural barriers in order to increase compliance with COVID-19 prevention behaviours ${ }^{1}$. 


\section{REFERENCES}

1. West R, Michie S, James Rubin G, Amlôt R. Applying principles of behaviour change to reduce SARSCoV-2 transmission. Nat Hum Behav. 2020;4(5):451-459. doi:10.1038/s41562-020-0887-9

2. Schwarzer R. Modeling health behavior change: How to predict and modify the adoption and maintenance of health behaviors. Appl Psychol. 2008;57(1):1-29. doi:10.1111/j.14640597.2007.00325.x

3. Nakkazi E. Obstacles to COVID-19 control in east Africa. Lancet Infect Dis. 2020;20(6):660. doi: $10.1016 / \mathrm{S} 1473-3099(20) 30382-0$

4. Capps R, Gelatt J. Barriers to COVID-19 Testing and Treatment: Immigrants without Health Coverage in the United States. United States; 2020. https://www.migrationpolicy.org/research/covid-19testing-treatment-immigrants-health-insurance. Accessed September 22, 2020.

5. Frieden J. Lack of Health Literacy a Barrier to Grasping COVID-19. https://www.medpagetoday.com/infectiousdisease/covid19/87002. Published June 10, 2020. Accessed September 8, 2020.

6. Bruton B, Edwards N. Barriers to mass testing for COVID-19 in Africa. Atlantic Council. https://www.atlanticcouncil.org/blogs/africasource/barriers-to-mass-testing-for-covid-19-in-africa/. Published April 17, 2020. Accessed September 8, 2020.

7. What you need to know about coronavirus (COVID-19). Australian Government Department of Health. https://www.health.gov.au/news/health-alerts/novel-coronavirus-2019-ncov-healthalert/what-you-need-to-know-about-coronavirus-covid-19. Published September 10, 2020. Accessed September 23, 2020.

8. Maasdorp J. How long should it take to get a COVID-19 test result? Here's the breakdown for each state. ABC News. https://www.abc.net.au/news/2020-08-11/how-long-should-it-take-to-get-acoronavirus-covid19-test-result/12545150. Published August 11, 2020. Accessed September 23, 2020.

9. Hamilton-Smith L. Parklands Christian College hit by coronavirus scare to remain closed another week as test result delays stretch patience. ABC News. https://www.abc.net.au/news/2020-08- 
04/coronavirus-queensland-parkland-christian-college-test-delays/12518538. Published August 4, 2020. Accessed September 23, 2020.

10. Vally, H. Got a COVID-19 test in Victoria and still haven't got your results? Here's what may be happening - and what to do. The Conversation. https://theconversation.com/got-a-covid-19-test-invictoria-and-still-havent-got-your-results-heres-what-may-be-happening-and-what-to-do-142821. Published July 16, 2020. Accessed September 25, 2020.

11. Some Victorians facing enormous delays in securing COVID test results. Sky News. https://www.skynews.com.au/details/_6175734385001. Published July 28, 2020. Accessed September 25, 2020.

12. McCaffery K, Dodd R, Cvejic E, et al. Disparities in COVID-19 related knowledge, attitudes, beliefs and behaviours by health literacy. Public Heal Res Pract. 2020; In Press.

13. Pickles K, Cvejic E, Nickel B, et al. COVID-19: Beliefs in misinformation in the Australian community. medRxiv Prepr Serv Heal Sci. August 2020. https://www.medrxiv.org/content/10.1101/2020.08.04.20168583v1. Accessed September 8, 2020.

14. Jordan J, Yoeli E, Rand DG. Don't get it or don't spread it? Comparing self-interested versus prosocially framed COVID-19 prevention messaging. PsyArXiv Prepr. 2020. https://psyarxiv.com/yuq7x/. Accessed September 22, 2020.

15. Yonemitsu, F., Ikeda, A., Yoshimura, N., Takashima, K., Mori, Y., Sasaki, K., Qian, K. \& Yamada, Y. Warning 'Don't spread' vs. 'Don't be a spreader' to prevent the COVID-19 pandemic. R Soc Open Sci. 2020; In press.

16. Michie S, van Stralen MM, West R. The behaviour change wheel: A new method for characterising and designing behaviour change interventions. Implement Sci. 2011;6(1):42. doi:10.1186/1748-5908-6-42

17. Basch CH, MohIman J, Hillyer GC, Garcia P. Public Health Communication in Time of Crisis: Readability of On-Line COVID-19 Information. Disaster Medicine And Public Health Preparedness. 2020;1-3 doi:10.1017/dmp.2020.151 
18. Grey A. Multilingual Australia is missing out on vital COVID-19 information. No wonder local councils and businesses are stepping in. The Conversation. https://theconversation.com/multilingual-australiais-missing-out-on-vital-covid-19-information-no-wonder-local-councils-and-businesses-are-steppingin-141362. Published June 29, 2020. Accessed September 22, 2020.

19. Cockburn P. Young Australians avoid COVID-19 news so traditional health messaging doesn't work. ABC News. https://www.abc.net.au/news/science/2020-08-07/why-young-people-are-avoidingcovid-news/12531468. Published August 7, 2020. Accessed September 22, 2020.

20. Bonner C, Nickel B, Pickles K. Young men are more likely to believe COVID-19 myths. So how do we actually reach them? The Conversation. https://theconversation.com/young-men-are-more-likely-tobelieve-covid-19-myths-so-how-do-we-actually-reach-them-143745. Published August 10, 2020. Accessed September 22, 2020.

21. Department of Health and Human Services Victoria | \$450 Coronavirus (COVID-19) Test Isolation Payment. Victoria State Government. https://www.dhhs.vic.gov.au/employee-isolation-paymentcovid-19. Published August 18, 2020. Accessed September 22, 2020.

22. Findlay J. Concerns stigma and fear might put people off from being tested for COVID-19. ABC News. https://www.abc.net.au/news/2020-09-17/covid-19-stigma-could-be-a-barrier-to-testing-hivadvocate-says/12603948. Published September 18, 2020. Accessed September 22, 2020.

23. healthdirect Symptom Checker. Health Direct. https://www.healthdirect.gov.au/symptomchecker/tool/basic-details. Published 2020. Accessed September 23, 2020.

24. Coronavirus (COVID-19) interactive self-assessment. Department of Health and Human Services Victoria. https://www.dhhs.vic.gov.au/coronavirus-self-assessment. Published June 19, 2020. Accessed September 23, 2020.

25. Dunn AG. Will online symptom checkers improve health care in Australia? Med J Aust. 2020;212(11):512-513. doi:10.5694/mja2.50621

26. Gollwitzer PM, Sheeran P. Implementation Intentions and Goal Achievement: A Meta-analysis of Effects and Processes. Adv Exp Soc Psychol. 2006;38:69-119. doi:10.1016/S0065-2601(06)38002-1 
medRxiv preprint doi: https://doi.org/10.1101/2020.09.24.20201236; this version posted September 25, 2020. The copyright holder for this preprint (which was not certified by peer review) is the author/funder, who has granted medRxiv a license to display the preprint in perpetuity.

It is made available under a CC-BY-NC-ND 4.0 International license .

27. Kwasnicka D, Presseau J, White M, Sniehotta FF. Does planning how to cope with anticipated barriers facilitate health-related behaviour change? A systematic review. Health Psychol Rev. 2013;7(2):129145. doi:10.1080/17437199.2013.766832

28. Plan and prepare. NSW Rural Fire Service. https://www.rfs.nsw.gov.au/plan-and-prepare. Accessed September 22, 2020.

29. Australia Reports. FluTracking. https://info.flutracking.net/reports-2/australia-reports/. Accessed September 22, 2020.

30. Grundy E, Mangiarulo M, Slattery P. SCRUB COVID-19 Survey Wave 7: How the health and compliance of Australians is changing over time. Behaviour Works Australia.

https://www.behaviourworksaustralia.org/scrub-covid-19-survey-wave-7-how-the-health-andcompliance-of-australians-is-changing-over-time/. Published September 2, 2020. Accessed September $22,2020$. 
medRxiv preprint doi: https://doi.org/10.1101/2020.09.24.20201236; this version posted September 25, 2020. The copyright holder for this preprint (which was not certified by peer review) is the author/funder, who has granted medRxiv a license to display the preprint in perpetuity.

It is made available under a CC-BY-NC-ND 4.0 International license .

\section{ACKNOWLEDGEMENTS}

We thank the participants of the longitudinal COVID-19 survey for their ongoing participation in this research. This study was not specifically funded, but in-kind support was provided by authors with research fellowships.

CB is supported by a National Health and Medical Research Council (NHMRC)/Heart Foundation Early Career Fellowship (\#1122788).

RD is supported by a University of Sydney fellowship (\#197589).

KM is supported by a National Health and Medical Research Council (NHMRC) Principal Research Fellowship (\#1121110). 